\title{
IRON CONTENT, HARDNESS AND ACCEPTABILITY OF BISCUITS FROM COMPOSITE CASSAVA AND WHEAT FLOURS SUBSTITUTED WITH GREEN SPINACH FLOUR
}

\author{
Rusdin Rauf $^{1}$, Nurdiana ${ }^{2}$, Dwi Sarbini ${ }^{3}$ \\ ${ }^{1,2,3}$ Nurition Science Department, Faculty of Health Science, Universitas \\ Muhammadiyah Surakarta \\ Email: ${ }^{1}$ rusdin.rauf@ums.ac.id, ${ }^{2}$ nurdiana.9886@gmail.com, ${ }^{2}$ dwi.sarbini@ums.ac.id
}

\begin{abstract}
The main cause of the high prevalence of iron deficiency anemia of children in Indonesia is the low intake of iron. Green spinach flour as a source of iron can be used as a substitution material in the manufacture of biscuits. The purpose of the study was to evaluate the effect of green spinach flour substitution on iron, hardness and acceptance levels of biscuits from composite cassava flour and wheat flour. The research was conducted by substituting the green spinach flour with various levels of $0 \%, 2.5 \%, 5 \%$ and $7.5 \%$. The biscuits were then tested for the iron using Atomic Absorption Spectrophotometer (AAS), hardness using texture analyzer and acceptability. The results indicated that there was a substitution effect of green spinach flour to iron and acceptability of biscuits, whereas, there was no effect on the hardness. The higher the substitution of green spinach flour, the higher the iron level of the biscuit. The highest iron level was displayed by biscuit with the substitution of $7.5 \%$, which was $89.82 \mathrm{mg} / \mathrm{kg}$. The hardness of biscuits was not affected by the substitution of green spinach flour. The range of biscuit hardness levels was between 2592.16g - 3985.83g. Biscuit with 5\% substitution of green spinach flour gave the highest acceptability. The iron requirement of Indonesian school-age children (7-9 years) can be fulfilled by consuming biscuits (5\% green spinach flour) as much as 14 grams or equivalent to 3 pieces of biscuit for a day.
\end{abstract}

Keywords: Acceptability, biscuit, hardness, iron, spinach

\section{INTRODUCTION}

Micronutrient deficiency is one of the most common health problems in many developing countries including Indonesia. Arisman (2010) reported that one of the problems of micronutrients in Indonesia is the incidence of iron deficiency anemia. An estimated $36 \%$ of 3800 million people in developing countries have suffered from anemia. According to Basic Health Research in
2013, the prevalence of anemia in Indonesia was $21.7 \%$, with anemia patients aged 5-14 years as many as $26.4 \%$ and $18.4 \%$ in patients aged $15-24$ years (Balitbang Kemenkes RI, 2013).

Anemia is a decrease in the number of red blood cells in the bloodstream or hemoglobin levels are below normal limits (Corwin and Elizabeth, 2009). Almatsier (2010) stated that low levels of hemoglobin can have an impact on the decline of the immune system, decreased 
the ability of physical work and decreased physical fitness. School-age children are among the high-risk age groups for anemia. According to Indonesian Recommended Dietary Allowances (2013) iron requirement for children with 7-9 years age range in both boys and girls is $10 \mathrm{mg}$ per day, while iron requirement at age 10-12 years is $13 \mathrm{mg}$ for boys and 20 $\mathrm{mg}$ for girls. The iron requirement in school-age children who are not balanced with adequate daily iron intake will have an impact on iron deficiency anemia. This condition can have a negative impact on school-aged children, namely inhibition of concentration and learning ability. The high risk of anemia has required a variety of handling efforts.

The effort to deal with iron anemia problem is by giving iron supplementation and consumption of food source of iron. Based on the source, there are two types of iron which are iron-heme and ironnonheme. Iron-heme is a type of iron in the hemoglobin and myoglobin of animal foods such as meat, chicken, eggs, and fish. While iron-nonheme is a type of iron in plant foods such as crushed cereals, green beans, and vegetables such as spinach (Samman, 2007).

Spinach is a source of vitamins and minerals that are cheap and easy to obtain. Iron content in spinach is quite high, which is about $2.71 \mathrm{mg} / 100 \mathrm{~g}$ (USDA, 2016). Spinach is also rich in $\beta$-carotene and vitamin C, respectively $11956.80 \mu \mathrm{g} /$ $100 \mathrm{~g}$ (Ogbadoyi et al., 2011) and $28.1 \mathrm{mg}$ $/ 100 \mathrm{~g}$ (USDA, 2016). The $\beta$-carotene can increase iron absorption 3 times higher, so it is well consumed by anemic patients (Pereira et al., 2004). Spinach has a high bioavailability compared to other vegetable iron sources. Zhang et al. (1985) supported that spinach administration may increase hemoglobin in anemic mice. Maramag et al. (2010) also reported that the consumption of vegetables rich in $\beta$ carotene may increase hemoglobin levels and reduce the prevalence of anemia in school-age children in the Philippines.

Although spinach is good for anemic people, consumption of vegetables in Indonesia, in general, is still low (Ministry of Agriculture, 2015). Spinach is usually processed by boiling and taken the juice for a drink or processed into a product. A variety of food products from spinach is still limited, so the need to develop the diversification of spinachbased products. One of the potential developed is the biscuit because it is liked by many people.

Nowadays, there has been much research related to the formulation of biscuits by using cassava flour. Cassava is an appropriate alternative to replace the role of wheat flour due to low production costs and high yield if processed into flour. Oluwamukomi et al. (2011) supported that biscuits with $40 \%$ substitution of cassava flour can produce a good level of crispy and can be accepted by the panelist. Nurdiana et al. (2015) reported that the formulation of $60 \%$ cassava flour and $40 \%$ wheat flour is the most preferred formula by panelists and resulted in the highest crack rate.

The provision of cassava biscuits substituted with spinach flour as a source of iron is one way to increase iron intake. The addition of spinach flour can affect the physical and organoleptic properties of biscuits such as color, flavor, taste, and texture. Therefore, further study on the formulation of the use of spinach flour in the manufacture of cassava biscuits. Cassava biscuits with the addition of spinach flour are expected to be a new innovation in the development of food to solve the problem of iron anemia as well as efforts to reduce the consumption of wheat flour.

The purpose of the research was to find out the effect of green spinach flour substitution to iron content, hardness, and acceptance of biscuits made from cassava 
and wheat flours composite.

\section{RESEARCH METHOD Materials}

The ingredients of biscuit making used in this study were wheat flour, cassava, green spinach, water, margarine, eggs, sugar, baking powder, and vanilla. Cassava and green spinach were obtained from traditional markets in Surakarta, while wheat, margarine, egg, sugar, baking powder and vanilla were derived from supermarkets in Surakarta. The $\mathrm{HNO}_{3}, \mathrm{HClO}_{4}$ dan distilled water were used for the iron analysis.

\section{Manufacture of Cassava Flour}

Manufacture of cassava flour to follow the procedure reported by Rauf and Sarbini (2015). Cassava was peeled and washed using flowing water. Furthermore, cassava was sliced thinly, followed by drying using a cabinet dryer at a temperature of $60^{\circ} \mathrm{C}$ for 20 hours. The dried strips were milled and sieved to 80 meshes.

\section{Manufacture of Green Spinach Flour}

Procedure of green spinach flour manufacture was modified from Rao et al. (2015). Green spinach was washed using flowing water. Furthermore, spinach leaves were dried using an oven dryer at $45^{\circ} \mathrm{C}$ for 20 hours. The dried leaves were milled and sieved to 80 meshes.

\section{Biscuit Making}

Procedure of biscuit production was reported by Nurdiana et al. (2015). An $85.70 \mathrm{~g}$ of sugar and $64 \mathrm{~mL}$ of water was heated until the sugar dissolves. After cooling, the sugar solution was mixed with $71.40 \mathrm{~g}$ margarine, $35 \mathrm{~g}$ eggs, $2.30 \mathrm{~g}$ baking powder and $3 \mathrm{~g}$ of vanilla. Then, it was mixed with $200 \mathrm{~g}$ of cassava-wheat flour composite and spinach flour until becoming dough. The dough was baked using the oven at $170^{\circ} \mathrm{C}$ for 20 minutes.

\section{Iron Measurement}

Iron was analyzed following the procedure of Salawu et al. (2015). Five grams of samples was added $15 \mathrm{~mL}$ of concentrated $\mathrm{HNO}_{3}$ and $5 \mathrm{~mL}$ of $\mathrm{HClO}_{4}$. It was then boiled until the solution became clear and white fumes of $\mathrm{HClO}_{4}$ appeared. It was added de-ionized distilled water to a total of $50 \mathrm{~mL}$ solution. The solution then was filtered. The iron content in the filtrate was determined using Atomic Absorption Spectrophotometer (AAS) at $248 \mathrm{~nm}$.

\section{Hardness Measurement}

Hardness measurement of biscuits as followed the procedure of Choy et al. (2010) using Brookfield CT3 texture analyzer. Some settings were test type compression, trigger point $20 \mathrm{~g}$, target value $3 \mathrm{~mm}$, no.cycles 1 , test speed 0.50 $\mathrm{mm} / \mathrm{s}$, probe type TA 18 , hold time $0 \mathrm{~s}$ and recovery time 0s. Hardness level is expressed as the amount of maximum compression force given on the biscuits to be deformed.

\section{Acceptability Measurement}

The acceptability test of biscuits was conducted by 30 panelists of Nutrition Science Department students, Universitas Muhammadiyah Surakarta. Samples were measured for color, aroma, texture, taste and overall. The test was based on 5-point hedonic scale, namely $1=$ dislike very much, 2 = dislike moderately, $3=$ like slightly, $4=$ like moderately, and $5=$ like very much. The panelists have been given an explanation of the samples to be tested and how to perform detailed testing. Panelists conducted the testing from the left sample to the right in sequence. Each treatment of the samples was given 3-digit random number code. The panelists wrote the results on the form. 


\section{Design and Statistical Analysis}

The research was conducted using completely randomized design, with 4 treatments of the substitution of spinach flour in biscuit making. Data were analyzed using Kruskall-Wallis, followed by Duncan's at a level 5\%.

\section{RESULT AND DISCUSSION Iron Content}

Statistical test using Kruskall-Wallis Test shows that there is no effect of substitution of green spinach flour on iron content of biscuits from cassava and flour composite flour. This is indicated by the significance value $\mathrm{p}=0.112(\mathrm{p}>0.05)$. The iron content of biscuits is displayed in Figure 1.

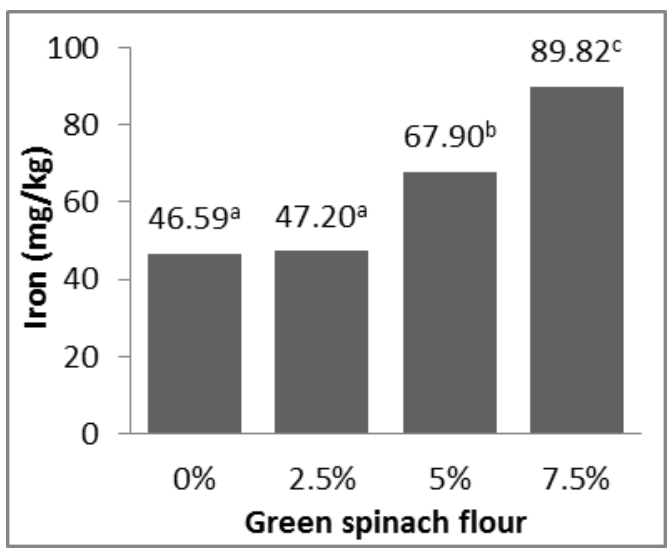

Figure 1. Iron levels of biscuits from composite cassava and wheat flours substituted with green spinach flour

The substitution of green spinach $0 \%$ and $2.5 \%$, in Figure 1, gives the iron content that is not significantly different. The highest iron content is given by biscuits with a substitution of $7.5 \%$ green spinach flour. The higher the substitution of green spinach flour, the higher the iron of the biscuits. This is in accordance with Borneo et al. (2008) that spinach flour can be used to increase the iron levels in food products.

The iron content of biscuits substituted with green spinach flour for every 100 grams of biscuits is in the range between 4.65-8.98 $\mathrm{mg}$ of iron. Biscuits can be consumed as snack foods which are usually given at $10 \%$ of the total daily requirement. If biscuits are consumed by school-age children (7-9 years), then the need for the iron from biscuits is $1 \mathrm{mg}$ per day from a total requirement daily according to Indonesian Recommended Dietary Allowances. This can be accomplished by consuming \pm 14 grams of biscuit substituted 5\% spinach flour or equivalent to 3 pieces.

\section{Hardness}

Statistically, there is no effect of green spinach flour substitution on the hardness of biscuits from composite cassava and wheat flours, with the significant value is $p=0.516 \quad(p>0.05)$. The hardness of biscuits is shown in Figure 2. The hardness of biscuits in a range between $2592.16 \mathrm{~g}$ to $3985.83 \mathrm{~g}$. The hardness of biscuits is affected by its protein content. High levels of protein can cause biscuits to become harder and less crunchy so that in the manufacture of biscuits required low protein wheat flour (Sindhuja et al., 2005).

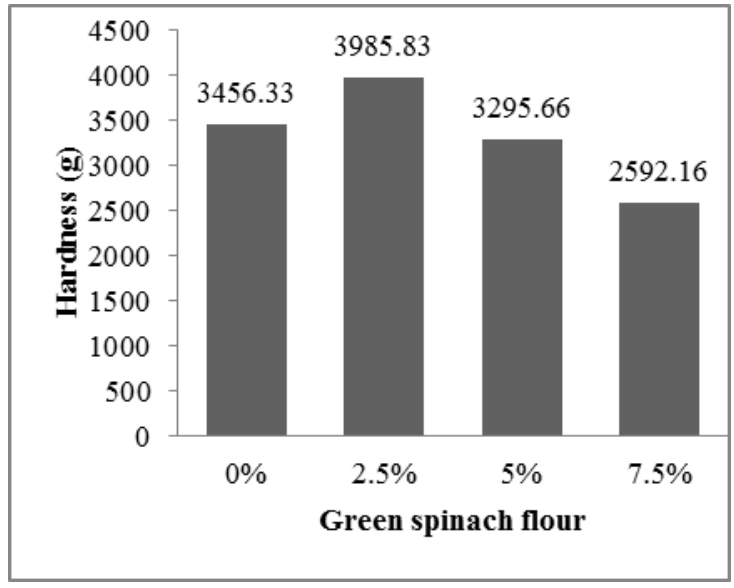

Figure 2. Hardness levels of biscuits from composite cassava and wheat flours substituted with green spinach flour 
In this research, the composite cassava flour and wheat flour used is in 60: 40 , so that the protein content of the composite becomes lower than wheat flour protein level. Gardjito et al. (2013) stated that the protein level of wheat soft flour is $9-10 \%$. Through the calculation, the protein content of cassava flour and wheat flour mixture is $4.42 \%-4.82 \%$.

Spinach flour has the high protein level, so the substitution can increase the protein content of composite flour. Rao et al. (2015) reported that spinach protein content of $28.23 \%$. Mathematically, after the substitution of $0 \%, 2.5 \%, 5 \%$ and $7,5 \%$ spinach flour, the protein contents of the composite flours are $4.42 \%, 5.02 \%$, $5.72 \%$, and $6.43 \%$, respectively.

The small contribution of protein is given by the spinach flour and the different types of protein between spinach flour and wheat flour resulted in no effect on the level of hardness of the biscuits. The difference in the type of protein between wheat flour and spinach flour is thought to be the cause of no effect on the hardness. Rauf (2015) stated that wheat flour has an advantage over the type of its constituent protein, gluten, which can strengthen the interaction between the dough components in the manufacture of the product. The interaction between these components affects the texture of the product.

\section{Acceptability}

Statistical test revealed that there is an effect of spinach flour substitution on color, aroma, taste, texture, and overall acceptability of biscuits. The acceptability of biscuits is displayed in Table 1 .
Table 1. Acceptability of biscuits substituted with green spinach flour

\begin{tabular}{llllll}
\hline \multirow{2}{*}{ Indicators } & \multicolumn{4}{c}{ Acceptability Score } & \multirow{2}{*}{$\boldsymbol{p}$} \\
\cline { 2 - 5 } & $0 \%$ & $2.5 \%$ & $5 \%$ & $7.5 \%$ & \\
\hline Color & $3.90^{b c}$ & $3.57^{a b}$ & $4.07^{c}$ & $3.27^{a}$ & 0.001 \\
Aroma & $3.77^{b}$ & $3.87^{b}$ & $3.87^{b}$ & $2.80^{a}$ & 0.001 \\
Taste & $3.73^{b c}$ & $3.47^{b}$ & $3.80^{c}$ & $2.70^{a}$ & 0.001 \\
Texture & $3.93^{b}$ & $3.90^{b}$ & $4.00^{b}$ & $3.50^{a}$ & 0.012 \\
Overall & $3.90^{b}$ & $3.77^{b}$ & $4.07^{b}$ & $2.97^{a}$ & 0.001 \\
\hline
\end{tabular}

The difference in the degree of substitution of green spinach flour, in Table 1, gives the difference in the acceptability of the color of the biscuits. Biscuit with the substitution of $5 \%$ green spinach flour shows the highest acceptability, while the $7.5 \%$ substitution provides the lowest acceptance. Nwakalor et al. (2014) reported that vegetable flour substitution has a positive effect on the acceptance of biscuit color. However, the substitution of vegetable flour at a high level can decrease the acceptability of biscuits color.

The aroma of biscuit with the substitution $0 \%, 2.5 \%$, and $5 \%$ shows the acceptability that is not significantly different. The difference appears in the highest substitution of $7.5 \%$. Fitriyani (2013) explained that spinach has a distinctive aroma, so easily detected when mixed with processed foods such as biscuits. Panelists give a "likes" rating on biscuits substituted $2.5 \%$ and $5 \%$. However, the panelists display a "dislike" to biscuit substituted $7.5 \%$. This is in accordance with Nwakalor (2014) that the higher the substitution of vegetable flour, the lower the acceptance of panelists on the aroma of biscuits.

The substitution of green spinach flour on each level gives a different liking score to taste attributes. The substitution of 5\% green spinach flour showed the highest acceptability. This is in accordance with Khan et al. (2015) that substitution of 5\% spinach flour in chapati, Indian food product, provides the highest taste acceptability. 
Substitutions of $0 \%, 2.5 \%$, and $5 \%$ indicated the acceptance of biscuit texture that is not significantly different. The difference is seen in the $7.5 \%$ substitution, with a lower acceptance score. Khan et al. (2015) stated that the highest acceptability of chapati texture is given by the substitution of $5 \%$, while the acceptability was low for higher substitution.

Overall acceptability of biscuits displays that there is no significant difference for $0 \%, 2.5 \%$, and $5 \%$ substitution. The $7.5 \%$ substitution revealed the lowest overall acceptability that tends to be disliked. Based on the overall acceptance score, 5\% substitution of biscuit indicates the highest acceptability.

\section{CONCLUSION}

The larger the substitution of green spinach flour, the higher the iron content of biscuits. The highest iron is obtained from biscuit substituted spinach flour $7.5 \%$, which is $89.82 \mathrm{mg} / \mathrm{kg}$ of iron. There is no difference in the degree of hardness of biscuits substituted with green spinach flour at various levels. There is a substitution effect of green spinach flour on biscuit acceptability.

\section{REFERENCES}

Almatsier, S. (2010). Prinsip Dasar Ilmu Gizi. Gramedia Pustaka. Jakarta.

Arisman. (2010). Gizi dalam Daur Kehidupan. EGC. Jakarta.

Balitbang Kementerian Kesehatan RI. (2013). Riset Kesehatan Dasar. Balitbang Kemenkes RI. Jakarta.

Borneo, R., Aguirre, A. (2008). Chemical Composition, Cooking Quality, and Cosumer Acceptance of Pasta Made with Dried Amaranth Leaves Flour. Journal of Food Sience and Technology, 41(2008), 1748-1751.

Choy, Ai-ling., J.G. Hughes, D.M., Small. (2010). The Effect of Microbial Transglutaminase, Sodium Steroyl Lactylate and Water on The Quality of Instant Fried Noodles. Journal of Food Chemistry, 122, 957-964.

Corwin, Elizabeth, J. (2009). Handbook of Pathophysiologi, 3rd Ed. EGC. Jakarta.

Fitriyani. (2013). Eksperimen Pembuatan Roti Tawar dengan Penggunaan Sari Bayam (Amaranthus sp). Food Science and Culinary Education Journal, 2252-6587.

Gardjito, M., Djuwardi, A., Harmayani, E. (2013). Pangan Nusantara. Kencana Prenada Media Group. Jakarta.

Kementerian Kesehatan RI. (2013). Permenkes RI NO 75 Tahun 2013 tentang Angka Kecukupan Gizi yang Dianjurkan bagi Bangsa Indonesia. Kementerian Kesehatan RI. 
Jakarta.

Kementerian Pertanian. (2015). Rencana Strategis Kementerian Pertanian Tahun 2015-2019. Kementerian Pertanian Republik Indonesia.

Khan, M. A., C. Mahesh, Anil Dutt Semwal, G. K. Sharma. (2015). Effect of spinach powder on physico-chemical, rheological, nutritional and sensory characteristics of chapati premixes. J Food Sci Technol. 2015 Apr; 52(4): 2359-2365.

Maramag, C. C., JD Ribaya-Mercado, P Rayco-Solon, JAA Solon, LW Tengco, JB Blumberg, FS Solon. (2010). Influence Of Carotene-Rich Vegetable Meals On The Prevalence Of Anaemia And Iron Deficiency In Filipino Schoolchildren. European Journal Of Clinical Nutrition 64, 468-474 (2010).

Nurdiana, Istinganah, M., Rahmatika, N. A. (2015). Tingkat Keretakan dan Daya Terima Biskuit dari Campuran Tepung Singkong dan Tepung Terigu. Laporan Penelitian Program Studi Ilmu Gizi Fakultas Ilmu Kesehatan Universitas Muhammadiyah Surakarta. Surakarta.

Nwakalor, Chizoba, N. (2014). Sensory Evaluation of Cookies Produced from Different Blends of Wheat and moringa Oleifera Leaf Flour. International Journal of Nutrition and Food Sciences. Vol. 3, No. 4, pp. 307-310.

Ogbadoyi, E.O., Amanabo, M., Johnson, A. O., Matthew, I. S. E. (2011). Effect of Processing Methods On Some Nutrients, Antinutrients and Toxic Substances In Amaranthus Cruentus. International Journal Of Applied Biology and Pharmaceutical Technology Vol 2.

Oluwamukomi, M. O.,I. B. Oluwalana, and O. F. Akinbowale. (2011). Physicochemical and sensory properties of wheat-cassava composite biscuit enriched with soy flour. African Journal of Food Science Vol. 5 (2) pp. 50 - 56 February 2011.

Pereira, R. C., Alcides, D. S. D., Luiz, O. C. F,. (2004). New Findings On Iron Absorbtion Conditioning Factors. 4 (3): 241-248 Juli 2004.

Rao, G.N., P.G. Prabhakara Rao, G. Sulochanamma, A. Satyanarayana. (2015). Physicochemical Amino acid composition, fatty acid profile, functional and antioxidant properties of Spinacia oleracea L. Leaf. Journal of food and Pharmaceutical Sciences 3(2015)27-37.

Rauf, R. (2015). Kimia Pangan. C.V Andi Offset. Yogyakarta. 
Rauf, R., Sarbini, D., (2015). Daya Serap Air sebagai Acuan untuk Menentukan Volume Air dalam Pembuatan Adonan dari Campuran Tepung Terigu dan Tepung Singkong. Agritech, 35 (3): 324-330.

Salawu, K., Barau, M. M., Mohammed, D., Mikailu, D.A., Abdullahi, B.H. and Uroko, R.I., (2016). Determination of some selected heavy metals in spinach and irrigated water from Samaru Area within Gusau Metropolis in Zamfara State, Nigeria. Journal of Toxicology and Environmental Health Sciences, 7(8): 76-80.

Samman, S., (2007). Iron. Nutrition \& Dietetics, 64 (Suppl. 4): S126 - S130

Sindhuja, A., Sudha, M. L., \& Rahim, A. (2005). Effect of incorporation of amaranth flour on the quality of cookies. European Food Research Technology, 221, 597-601.

Zhang, D., Deloy G. H., Arthur W. M., Daren P. C. (1985). Bioavailability of Iron in Green Peas, Spinach, Bran Cereal, and Cornmeal fed to Anemic Rats. Journal of Food Science. Voleme 50, Issue 2, p 426-428, March 1985. 